\title{
Impulsive Buying, Post-purchase Regret, and Credit Card
}

\author{
L. Verina Halim Secapramana ${ }^{1 *}$, Gracia Jason Magdalena ${ }^{2}$, Listyo Yuwanto ${ }^{3}$ \\ ${ }^{1,2,3}$ Faculty of Psychology, University of Surabaya, Indonesia \\ *Corresponding author. Email : verina@staff.ubaya.ac.id
}

\begin{abstract}
Impulsive buying is an unplanned purchase and is coloured by a strong urge that is difficult to resist buying suddenly. It is usually triggered by external conditions when dealing with products, accompanied by the arising of pleasant and passionate feelings with the consequences of anxiety, regret, and sometimes debt as well. It is suspected that it has something to do with the use of credit cards. This study was conducted in 249 early adult women aged between 18 and 22 years. The research method used is a quantitative survey with convenient sampling. A linear regression test is used for data analysis. The results showed a relationship between the three variables, in a positive direction. The higher the tendency to use credit cards, the higher the impulsive buying, and the higher the post-purchase regret that results. The practical implication of this research is the importance of discount as a promotional tool, in addition to the product's appearance and store atmosphere. Credit cards are one of the functional strategies that offer practicality, convenience, and safety for consumers. Although the use of credit cards facilitates the payment process, consumers should be wiser in using them, given the possibility of increased impulsive buying and post-purchase regret that can arise.
\end{abstract}

Keywords: Impulsive buying, post-purchase regret, credit card.

\section{INTRODUCTION}

The economic growth of a country influences the lifestyle of its people, including the pattern of shopping. Increased economic growth in Indonesia has made people prefer to do daily necessity shopping transactions in modern retail outlets that are self- service compared to traditional outlets (www.kppu.go.id). Changing patterns of Indonesian public spending into a business opportunity in the modern retail business.

People turn into consumers who "love shopping" and consider shopping as a means of recreation, so that modern retail businesses begin to glance because it is known as a business that has positive cash flow. Consumers tend to pay in cash, while retailers pay

Rp. 297.76 trillion, with the dominance of spending for Rp. 288.91 trillion [3].

Research from Khare [4] concluded that credit cards suppliers on credit. Marketers or retailers must implement a variety of strategies in their stores that can make consumers spend their maximum money while shopping [1]. To win the competition between outlets, each retailer seeks to provide various stimuli, such as arranging products and the physical environment in such a way as to be attractive, making attractive sales promotions, including providing credit card payment facilities to provide more comfort to consumers, while increasing the possibility to shop more for those who don't carry enough cash. Data from Bank Indonesia in 2015 the use of credit cards reached 10-12 percent of purchase transactions with total transactions reaching 281.31 million times with a value of Rp. 280, 54 trillion [2]. In 2017 the value of credit card transactions reached

allow consumers to show their status to others and communicate one's position in society. Ease of making transactions makes one need not worry when shopping 
if you do not carry or do not have cash, because he can still make purchases with a credit card.

When visiting places to shop, consumers tend to make purchases that are not planned before. The work done by each individual when making decisions in buying activities is different from one purchase to another. Sometimes decision making is done spontaneously, with little information, and low involvement. This type of unplanned purchase is referred to as impulsive buying [5]. Impulse is a sudden desire to behave in a certain way. This happens when individuals do something more emotionally based than based on reasoned analysis Hoyer \& MacInnis [6] defines impulsive buying as a purchase that occurs when a consumer suddenly decides to buy something that was not planned to be bought before. Impulsive buying is part of the pattern of consumer purchases in which purchasing decisions are made while in a store and at that moment consumers experience a sudden immediately Belk, 1995 in [7]. Rook in [8] states that the difference between impulsive buying and rational buying is the presence of an increased emotional factor, an urge to consume, and a psychological tendency to make an immediate purchase. Impulsive purchases usually involve high emotional responses and occur without a plan [9].

After making a purchase, consumers will evaluate the goods that have been purchased. The evaluation process will determine whether someone is satisfied with the items purchased or not. Consumers want to convince themselves that the product purchased can solve problems and can satisfy their needs [10]. It is not uncommon for consumers to compare products they have purchased with products they did not buy. Comparisons

between these products can cause a psychological condition known as cognitive dissonance or postpurchase regret [11]. Regret can occur when consumers compare the results of products that have been purchased with the results of products that might be obtained if consumers buy other products (Bell, 1982; Tsiros \& Mittal, 2000 in [12].

One of the characteristics that can influence postpurchase regrets is impulsivity. Consumers who make impulsive purchases tend to feel regret towards the choices made compared to consumers who do not make impulsive purchases. This is due to the lack of effort to search for information during the decision-making process, due to the dominance of the emotional element compared to the rational element [13]. Research from Saleh [11] shows that unplanned purchases have a positive effect on post-purchase regret, with a stronger intensity on low-income consumers compared to highincome consumers. Sales promotion is not significantly positively related to unplanned buying, while bank card payment has a positive effect on unplanned buying. Research from Arslan [14] found that comfort and image factors on the use of credit cards have an impact on impulsive buying.

\section{METHODS}

The research data were obtained directly from distributing questionnaires. They use credit cards in purchasing fashion products. Sampling using convenient sampling techniques. All items are measured using a Likert scale, ranging from 1 to 4 . Impulsive buying is measured based on 7 dimensions from Beatty $\&$ Ferrel [15]. The number of items is 21 items. Postpurchase regret will be measured by 16 questionnaire items adapted from Lee \& Cotte's [12] study. Credit card payments are measured by 4 items questionnaire adapted from Mahmoud Saleh [11]. Data were analysed using simple regression analysis techniques 


\section{RESULT}

Table 1. Sample Frame of Respondents

\begin{tabular}{|c|c|c|c|}
\hline Group & Particulars & Frequency & Percentage \\
\hline \multirow[t]{2}{*}{ Age } & $18-19$ & 49 & 19.6 \\
\hline & $20-22$ & 200 & 80.4 \\
\hline \multirow[t]{2}{*}{ Job } & Student & 215 & 86.3 \\
\hline & Employee & 34 & 13.7 \\
\hline \multirow[t]{6}{*}{ Expenditure } & Up to IDR 500.000 & 93 & 37.3 \\
\hline & IDR 500.001-1.000.000 & 95 & 38.1 \\
\hline & IDR 1.000.001-2.000.000 & & \\
\hline & IDR 2.000.001-3.000.000 & 37 & 14.9 \\
\hline & & 12 & 4.8 \\
\hline & Above IDR 3.000.001 & 12 & 4.8 \\
\hline \multirow{7}{*}{$\begin{array}{l}\text { Having plan } \\
\text { buying } \\
\text { Item to buy }\end{array}$} & No & 163 & 65.5 \\
\hline & Yes & 86 & $34 / 5$ \\
\hline & Clothes & 154 & 75.9 \\
\hline & Shoes & 71 & 35 \\
\hline & Skin care & 7 & 3.4 \\
\hline & Bags & 19 & 9.4 \\
\hline & Accessories, & 89 & 43.8 \\
\hline \multirow{7}{*}{$\begin{array}{l}\text { Factors driving } \\
\text { unplanned buying }\end{array}$} & Others & 6 & 3 \\
\hline & Discount & 197 & 33.3 \\
\hline & Price & 136 & 23 \\
\hline & Product display & 124 & 21 \\
\hline & Needs & 114 & 19.3 \\
\hline & Store atmospher & 13 & 2.2 \\
\hline & Others & 7 & 1.2 \\
\hline \multirow[t]{4}{*}{ Emotion after buying } & Happy & 216 & 59.5 \\
\hline & Excited & 121 & 33.3 \\
\hline & Ordinary & 21 & 5.8 \\
\hline & Others & 5 & 1.4 \\
\hline \multirow{2}{*}{$\begin{array}{l}\text { Buy immediately when } \\
\text { viewing the desired item }\end{array}$} & Yes & 126 & 50.6 \\
\hline & No & 104 & 41.8 \\
\hline \multirow{10}{*}{$\begin{array}{l}\text { Reasons not to buy right } \\
\text { away }\end{array}$} & $\begin{array}{l}\text { Depends on the condition } \\
\text { Budget }\end{array}$ & 19 & 7.6 \\
\hline & Adjusting needs & 43 & 34.1 \\
\hline & Price consideration & 21 & 16.7 \\
\hline & Rethinking & 16 & 12.7 \\
\hline & Consideration of function & 8 & 6.3 \\
\hline & $\begin{array}{l}\text { Compare with other } \\
\text { stores or products }\end{array}$ & 4 & 3.2 \\
\hline & $\begin{array}{l}\text { Quality considerations } \\
\text { Looking for references }\end{array}$ & 4 & 3.2 \\
\hline & Depends on mood & 3 & 2.4 \\
\hline & No reason & 2 & 1.6 \\
\hline & Fear of thinking when not & 2 & 1.6 \\
\hline \multirow{8}{*}{$\begin{array}{l}\text { Reasons to buy right } \\
\text { away }\end{array}$} & buying & 23 & 18.2 \\
\hline & $\begin{array}{l}\text { Fear of running out of } \\
\text { goods }\end{array}$ & 25 & 24 \\
\hline & $\begin{array}{l}\text { Like the product } \\
\text { Out of necessity }\end{array}$ & 17 & 16.3 \\
\hline & Having budget & 15 & 14.4 \\
\hline & Want to buy & 10 & 9.6 \\
\hline & Interesting & 10 & 9.6 \\
\hline & To be satisfied & 6 & 5.8 \\
\hline & There is a promotion & 3 & 2.9 \\
\hline
\end{tabular}




\begin{tabular}{|c|c|c|c|}
\hline \multirow{3}{*}{$\begin{array}{l}\text { Spend a lot of time when } \\
\text { shopping }\end{array}$} & Yes & 2 & 1.9 \\
\hline & No & 1 & 1 \\
\hline & Sometimes & 174 & 69.9 \\
\hline \multirow{3}{*}{ Reason for answering yes } & Compare before buying & 66 & 26.5 \\
\hline & Love shopping & 9 & 3.6 \\
\hline & Consider before buying & 59 & 33.9 \\
\hline \multirow{5}{*}{ Reason for answering no } & $\begin{array}{l}\text { Others } \\
\text { Already feel suitable }\end{array}$ & 47 & 26.9 \\
\hline & Don't like shopping too & 29 & 16.7 \\
\hline & long & 39 & 22.4 \\
\hline & Already determine the & 18 & 27.3 \\
\hline & items to be purchased & 18 & 27.3 \\
\hline \multirow{6}{*}{$\begin{array}{l}\text { Considerations before } \\
\text { making a purchase }\end{array}$} & Others & & \\
\hline & Product price & 8 & 12.1 \\
\hline & $\begin{array}{l}\text { Product function } \\
\text { Product durability }\end{array}$ & 22 & 33.3 \\
\hline & Comparing with other & 203 & 36.4 \\
\hline & products & 128 & 23 \\
\hline & Nothing & 122 & 21.9 \\
\hline \multirow{3}{*}{$\begin{array}{l}\text { Factors that determine } \\
\text { satisfaction when buying } \\
\text { a product }\end{array}$} & & 93 & 16.7 \\
\hline & Product function & 11 & 2 \\
\hline & $\begin{array}{l}\text { Comparing with other } \\
\text { similar products }\end{array}$ & & \\
\hline \multirow{7}{*}{$\begin{array}{l}\text { Information sought } \\
\text { before making a purchase }\end{array}$} & The decision making & 180 & 45.1 \\
\hline & process before buying & 146 & 36.6 \\
\hline & Time required & & \\
\hline & Others & 46 & 11.5 \\
\hline & Product price & & \\
\hline & Product brand & 11 & 2.8 \\
\hline & Product specification & 16 & 4 \\
\hline \multirow{5}{*}{$\begin{array}{l}\text { Which is preferred as a } \\
\text { means of payment }\end{array}$} & Product function & 188 & 29.5 \\
\hline & Comparing with other & 122 & 21.9 \\
\hline & products & 119 & 18.7 \\
\hline & Nothing & 94 & 14.7 \\
\hline & Credit card & 93 & 14.6 \\
\hline \multirow{4}{*}{$\begin{array}{l}\text { Reasons to prefer credit } \\
\text { cards }\end{array}$} & Cash & & \\
\hline & Depends on the condition & 22 & 3.5 \\
\hline & Practical & 124 & 49.8 \\
\hline & As an alternative & 113 & 45.4 \\
\hline \multirow{11}{*}{$\begin{array}{l}\text { Reasons to prefer paying } \\
\text { cash }\end{array}$} & There is a promotion & 12 & 4.8 \\
\hline & $\begin{array}{l}\text { Others } \\
\text { Spending is more }\end{array}$ & 65 & 52.4 \\
\hline & controlled & 15 & 12.1 \\
\hline & Practical & 3 & 2.4 \\
\hline & More flexible & 31 & 25 \\
\hline & Secure & 40 & 35.3 \\
\hline & $\begin{array}{l}\text { No charge } \\
\text { Others }\end{array}$ & 16 & 14.2 \\
\hline & & 9 & 8 \\
\hline & & 2 & 1.8 \\
\hline & & 2 & 1.8 \\
\hline & & 42 & 37.1 \\
\hline
\end{tabular}


Table 2. Hypothesis Testing Results

\begin{tabular}{lllllll}
\hline & $\mathrm{R} 2$ & $\mathrm{Std} \beta$ & $\mathrm{Un} \beta$ & $\mathrm{SD}$ Error & $\mathrm{T}$ & $\mathrm{P}$ \\
\hline $\begin{array}{l}\text { Credit card } \\
\text { with }\end{array}$ & 0.418 & $\beta 2=$ & $\mathrm{un} \beta 2=2.318$ & $\mathrm{~S} \beta 2=0.174$ & 13.322 & 0.000 \\
$\begin{array}{l}\text { impulsive } \\
\text { buying }\end{array}$ & & 0.647 & & & & \\
$\begin{array}{l}\text { Credit card } \\
\text { with post- }\end{array}$ & 0.146 & $\beta 1=0.174$ & $\mathrm{un} \beta 1=0.540$ & $\mathrm{~S} \beta 1=0.240$ & 3.191 & 0.025 \\
$\begin{array}{l}\text { purchase } \\
\text { regret }\end{array}$ & & & & & \\
$\begin{array}{l}\text { Impulsive } \\
\begin{array}{l}\text { buying with } \\
\text { post-purchase } \\
\text { regret }\end{array}\end{array}$ & 0.146 & $\beta 1=0,246$ & $\mathrm{un} \beta 1=0.214$ & $\mathrm{~S} \beta 1=0.067$ & 2.250 & 0.002 \\
\hline
\end{tabular}

\section{DISCUSSION AND CONCLUSION}

The result of the study showed that there is a significant relationship between credit cards with impulsive buying, and impulsive buying also has a significant relationship with post-purchase regret. The higher the use of credit cards, the more impulsive buying they eat, followed by the increasing post-purchase regret. Most respondents have a high level of impulsive buying, credit card use, and post-purchase regret too. The factor that most causes consumers to do impulsive buying is discount as an effective form of promotion that can attract the attention of consumers and encourage them to buy the products offered. Besides the price of goods, product appearance, needs, and store atmosphere also encourage consumers to do impulsive buying. Mowen and Minor (2001) in [16] found that most respondents make purchases more because they like to buy goods rather than needing so that the purchase is unplanned and the purchase choices are made right away because of strong positive feelings about an item. Most respondents feel happy when shopping, as is the characteristic of impulsive buying according to Jeon (1990) in [15], that is feeling happy, happy, and enthusiastic that causes someone to be generous to respect themselves. Consumers feel as if they have more freedom to act, and will produce behaviours aimed at maintaining positive feelings in the form of shopping. The availability of time also affects someone to make impulsive purchases.

According to Zimmere and Scarborough [17] comfort is a factor that is highly expected by consumers when shopping. Payment using a credit card provides its convenience, because of the convenience it offers. The reason for using a credit card is because it is considered practical and can be an alternative when consumers do not bring cash. While some respondents prefer to use cash, even though they have a credit card because they are more able to control spending. The use of cash can occur felt more "pain" because consumers give a portion of "his property", which is not experienced when used is a credit card. When the use of credit cards becomes uncontrolled, there will be feelings of regret in consumers after making a purchase. One of the things that causes this feeling is that impulsive buying has been done. A significant positive correlation between these two variables proves this. Regret is influenced by two factors, namely disposition and situation factors. Disposition factors that influence remorse are self-esteem, social comparison, doubt, age, sex, and impulsivity [13]. While the situation factors include a sense of responsibility for the choices made, a gap between expectations and reality, choices between brands and prices, type of purchase, time in decision making, store service, involvement, and the existence of choices for other products.

After making a purchase, the consumer will conduct an evaluation, which will determine whether or not someone is satisfied with the product that has been purchased. In this study, it was found that the factor that most determines a person's satisfaction with the product that has been purchased is the function of the product itself, as well as a comparison with other products. Postpurchase outcome regret is a comparison of an individual's assessment of the results of what has been purchased and what might be bought. Whereas the postpurchase process regret arises when individuals compare poor decision-making processes with better decision-making processes that are possible [12].

Most respondents (68.3\%) experienced post-purchase outcome regret. Regret can occur because consumers feel sorry for not choosing another product, after evaluating the results by comparing what they have got with what they should be able to get [18]. The most sought after and considered information before consumers make a purchase is the price of the product, as well as the brand. Simonson [19] found that there is a two-way relationship between regret and choice between brand and price. Consumers tend to choose expensive products from brands that are already known to avoid feelings of regret. 
From the discussion above it can be concluded that the credit card will encourage someone to do impulsive buying, because of the practicality, convenience, and ease of payment methods offered. This is in line with research from Saleh [11] who found that credit cards will encourage someone to make an impulsive purchase. Arslan [14] also found that comfort and image factors when using credit cards had an impact on impulsive buying. After making a purchase, consumers who make impulsive buying will tend to feel post- purchase regret, due to lack of consideration before deciding to make a purchase [20]. Wood [21] who conducted a literature review of this relationship concluded that impulsive buying encourages someone to feel sorry and angry.

From the marketing perspective, this research has practical implications in the form of the importance of giving discounts as the most effective promotion to enable purchases, considering the price of goods is the factor most considered by consumers. Another thing to consider in marketing characteristics is the appearance of the product and the atmosphere of the store. A credit card payment facility is one of the company's functional strategies that offer practicality, convenience, and security for consumers. From the consumer side, especially credit card users can be warned to be more careful in using credit cards, to prevent impulsive buying and the emergence of post- purchase regrets.

\section{REFERENCES}

[1] Kanjaya, Meshvara dan Susilo, Yongki. Retail Rules : Melihat Keunggulan dan Potensi Bisnis Ritel Makanan di Masa Depan. 2010.

[2] Himawan, A. AKKI Prediksi Pertumbuhan Transaksi Kartu Kredit 2016. http://www.suara.com/bisnis/2016

[3] Djumena, E. Data Kartu Kredit Harus Dilaporkan ke Ditjen Pajak. https://ekonomi.kompas.com/read/2018/02/04/08 0800 326/

[4] Khare, Arpit. Money Attitudes, Credit Card, and Compulsive Buying Behaviour : A Study on Indian Consumers. International Journal of Business

Competition and Growth. 2016, Vol. 5 No. 1/2/3.

[5] Solomon, M., Bamosssy, G. Askegaard, S. \& Hogg, M.K. Consumer Behavior: An European Perspective. 3rd Edition. 2010. Harlow, England: Prentice Hall

[6] Hoyer, W. \& MacInnis, D.J. Consumer Behavior. 2nd Ed. 2010. Boston: Houghton Miffin Company

[7] Dittmar, Helga. Compulsive Buying - A Growing Concern? An Examination of Gender, Age, and Endorsement of Materialistic Values as Predictors. 2005. British Journal of Psychological
Society.

[8] Earl, P.E. \& Kemp, S. The Elgar Companion to Consumer Research and Economic Psychology. 1999. Northhampton : Edward Elgar Publishing Limited.

[9] Herabadi, A.G. Buying Impulse : A Study of Impulsive Consumption. Unpublished Dissertation. 2003. University of Nijmegen, The Netherlands.

[10] Bakshi, S. Impact of Gender on Consumer Purchase Behavior. Abhinav National Monthly Refereed Journal of Research in Commerce \& Management. 2012. 1 (9), 1-8.

[11] Saleh, M.A.H. An Investigation of the Relationship between Unplanned Buying and Post- purchase Regret. International Journal of Marketing Studies. 2012. Vol. 4, number 4, 106120.

[12] Lee, S.H. \& Cotte, J. Post-purchase Consumer Regret: Conceptualization and Development of the PPCR Scale. Advances in Consumer Research. 2009. 36, 456-462

[13] M'Barek, M.B. \& Gharbi, A. The Moderators of Post Purchase Regret. Journal of Marketing Research \& Case Studies. 2011. Article ID 511121

[14] Arslan, B. The Influence of Credit Card Usage on Impulsive Buying. 2015. International Journal of Physical and Social Sciences, 5 (7).

[15] Beatty, S.E. \& Ferrel, M.E. Impulse Buying: Modeling its Precursors. Journal of Retailing. Volume 74. Issue 2. Summer 1998. p: 169-191

[16] Gultekin, Beiza. \& Ozer, Leyla. Store Image's Influence on Perceived Quality of Store Brands and Store Brand Purchasing Behavior. Mediterranean Journal of Social Sciences. 2012. Vol 3 (March).

[17] Zimmerer, Thomas W., Scarborough, Norman M. \& Doug Wilson. Kewirausahaan dan Manajemen Usaha Kecil. 2009. Jakarta: Salemba Empat.

[18] Sugden, R. Regret, Recrimination and Rationality. Theory and Decision. 1985, Vol. 19 (1): 77-99.

[19] Simonson, I. The Influence of Anticipating Regret and Responsibility Purchase Decision. Journal of Consumer Research. 1992. Vol. 19 (1): 105-118.

[20] Hoch, J. \& Loewestein, G. Time-inconsistent Preferences and Consumer Self-control. Journal of Consumer Research, 1991, 17-492-507.

[21] Wood, M. Socio-Economic Status, Delay of Gratification and Impulsive Buying. Journal od Economic Psychology, 1998, 19(3), 295-320 